\title{
VIOLENCE AGAINST PREGNANT FEMALES, SITUATION IN CAIRO 2018
}

\author{
Amani Abdel Fattah, Mervat Hamdy, Ghada Hasabo \\ Forensic \& Clinical Toxicology Department, Faculty of Medicine, Cairo University \\ Amani Abdel Fattah: dr amaniforensic@yahoo.com Tel.: 01001153872
}

\begin{abstract}
Any act of gender-based violence that results in, or is likely to result in, physical, sexual or mental harm or suffering to women, including threats of such acts, coercion or arbitrary deprivation of liberty, whether occurring in private or public life as defined by United Nations.Violence against women is a world-wide problem and this study focused on clearing the factors in the Egyptian capital that are associated with this phenomenon during the pregnancy through asking cases who get exposed to violence during this period, and to name the common sequelae and complications due to exposure to different types of violence. Those cases visited the Gynaecology and Obstetric clinic at Kasr -Al Aini hospital during February 2018. There are serious complications of violence during pregnancy but the psychological affection seems to be the main problem after exposure to violence in this special period of female life and of course this needs a lot of support and long-term rehabilitation. Methodology: A cross-sectional study was done through spreading a simple formatted questionnaire among 218 women who were receiving antenatal care or those visiting the gynecology outpatient clinic at Kasr Al-Ainy teaching hospital through February 2018. Results: the study showed that the physical form of violence $(77.4 \%$ ) was more common than sexual form. Regarding exposure to physical violence; hematoma was the commonest complication (82.4\%). In most of cases (94\%), exposure to violence affected the violated women mostly in the form of permanent psychological trauma. Recommendations: more researches on different types of violence against women are necessary in different periods of women life as well as different social levels and more empowerment of women is recommended.
\end{abstract}

KEY WORDS: Gender based violence, violence during pregnancy, suffering to women, complications

\section{INTRODUCTION}

Domestic violence against women represents one of the most common form of human rights violation in the whole world (Bunch 1990; and Mezey et al., 2005). This violence may result in dramatic consequences on all levels. It may cause physical, psychological as well as sexual harm or suffering of women whether it occurs in private or public places. A study around the world reported a prevalence estimate between $3.8 \%$ and $8.8 \%$ (Devries 2010; Gazmararian 1996; and Durand and Schraiber 2007). Review studies indicate that approximately $1-8 \%$ of pregnant women in developed and approximately $4-29 \%$ in developing countries report some type of intimate partner violence. 
There are various factors related to violence against women. They may may include: poverty, lack of social support, black race/ethnic group and young age ( Gazmararian et al., 1996; and Nasir and Hyder 2003). As to the reproductive history of women, the following events were found to be associated to domestic violence: under 19 years of age at first sexual intercourse, unplanned pregnancy, partner's refusal to use condoms and the use of legal and illegal drugs. Pregnant women who have been exposed to violence in their young age were more susceptible to suffering violence during pregnancy (Gazmararian et al., 1996). Pregnancy presents one of the best ways to detect the extent and the frequency of domestic violence because pregnant women make regular visits during this period.

Violence against women during pregnancy may have harmful consequences for both women's health, as well as child's heath. Regarding women's heath, violence may lead to severe hemorrhages and the termination of pregnancy (Coker et al, 2004). Regarding the child's health, there is an increased risk for perinatal mortality, low birth weight or prematurity (Devries, 2010).

\section{METHODOLOGY}

A cross-sectional study was done through spreading a simple formatted questionnaire among 218 women who were receiving antenatal care or those visiting the gynecology outpatient clinic at Kasr AlAiny teaching hospital through February 2018. The questionnaire included variables related to: demographic and socioeconomic characteristics of the pregnant women and their intimate partners, maternal exposure to violence during current or previous pregnancy, causes and characters and types of this violence, the bad consequences of violence during pregnancy, and the probability of alcohol and drugs of abuse consumption by their husbands.

Analysis of interview of results was done and demonstrated in charts and pies in order to highlight some important results and simplify the core message of this work

\section{RESULTS}

This study was conducted among Egyptian females whose age ranging from 18- 55 years who were visiting the Gynaecology \& Obstetrics outpatient clinic in kasr Al- Ainy Educational Hospital in Cairo which represents the largest hospital in whole Egypt. The participants were pregnant at the time of conducting study or mothers who get exposed to violence during previous pregnancy.

In order to make this study more representative to the different geographical distribution in Egypt, about half of participant of the sample was from urban areas $(48.8 \%)$ and the other half was from rural areas around great Cairo.

Regarding the social status of participants, most of the sample members were still married at time of sharing in this study $(93.1 \%)$ as they decided to complete their marital life in spite of facing problem of violence, while the rest of the sample were divorced or widows.

As expected, this study showed that about two-thirds of violated women (68.2\%) had repeated exposure to different types of violence while the remaining third get exposed once to violence and those were women who get exposed to abortion or left home after the home after this insult.

While exploring the most common cause of violence from the point of view of victims, it was found that social factors 
(58.5\%) like personal behavior and attitude took the 1St place, the financial causes like poverty and unemployment were representing 24\%, and others causes (17.5\%) including partner drug or alcohol abuse.

About three-fourths of the sample were not working and just $25 \%$ were working with personal income, and it was not surprising to find that $32.3 \%$ of them were completely illiterate, only $6 \%$ were highly educated and around half of them had just basic education then stop as shown in Fig. (1).

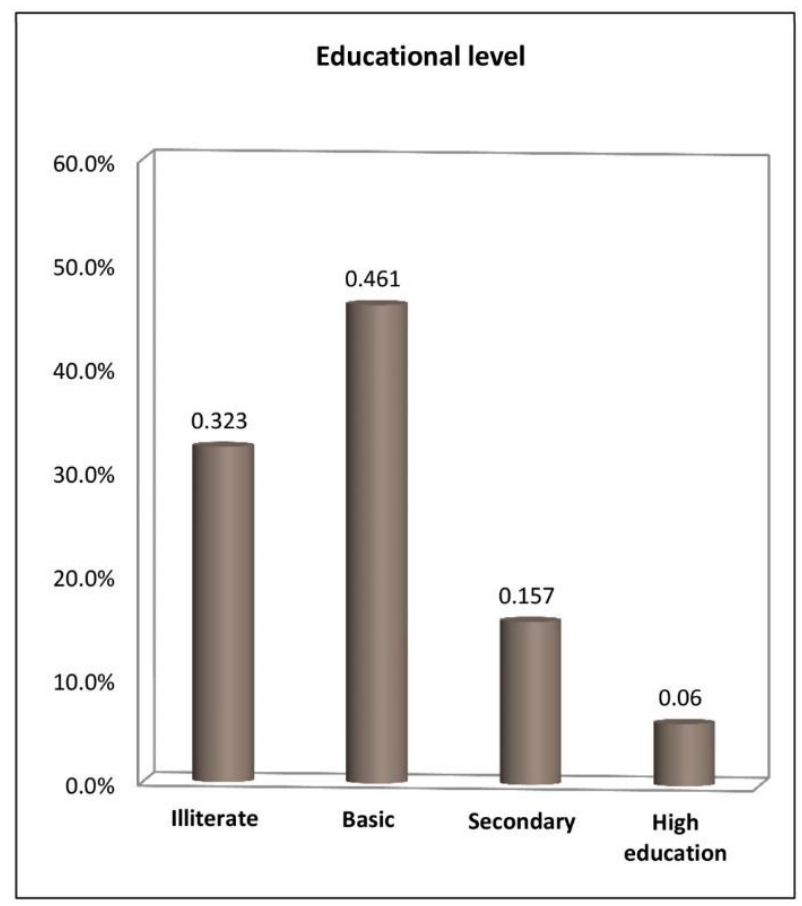

Figure (1): Level of education of the sample participants

While almost all cases get exposed to verbal and psychological violence, the study showed that the physical form of violence $(77.4 \%)$ was more common than sexual form, pure sexual violence (mostly through enforcing the women in a sexual relation) represented only $5.5 \%$, and about $17.1 \%$ get exposed to both physical and sexual.
Regarding exposure to physical violence; hematoma was the commonest complication $(82.4 \%)$ that ended in most of cases with complete healing, fortunately the serious complications like head injuries and fractures were not that common. The assailant mostly use bare hands in about $64.4 \%$ of cases, the rest used blunt objects (e.g sticks,....).

Unfortunately but expectedly the husband (intimate partner violence) was the accused person in $94.5 \%$ of cases, and the great news was that the pregnancy was not affected in $60.4 \%$, the affected cases ended in $40 \%$ with abortion, $34.9 \%$ had vaginal bleeding, $5.8 \%$ entered a preterm labour, while $18.6 \%$ of all other affections contributed to non serious of pregnancy complications which is clear in Fig. (2).

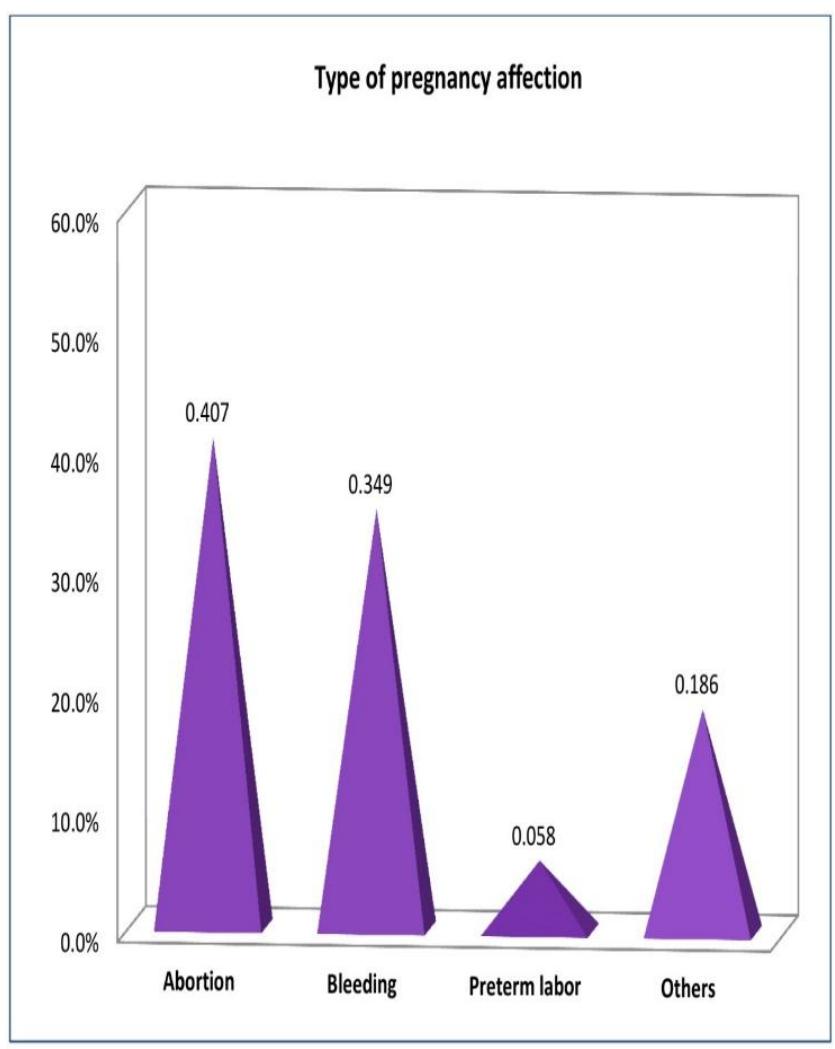

Figure (2): Types of pregnancy affection due to exposure to domestic violence 
As it is really unpleasant and not an easy experience the study showed that in most of cases (94\%), exposure to violence affected the violated women mostly in the form of permanent psychological trauma, that ranging widely from sense of being non secure till reaching the level of documented psychological disease Fig.( 3), while only $2.5 \%$ of cases had physical permanent infirmity.

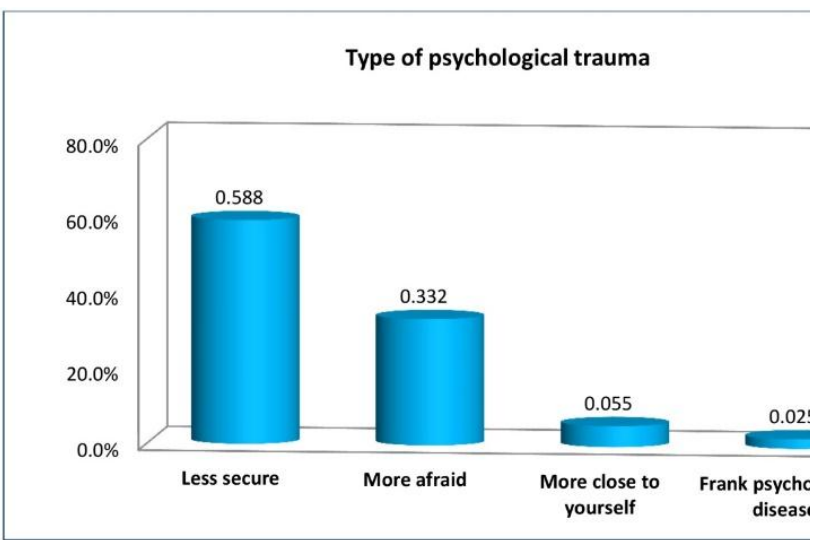

Fig (3): Different types of psychological trauma that the cases suffered from as a result of exposure to domestic violence during pregnancy

\section{DISCUSSION}

Bowen et al. (2015) showed in their study that unlike other studies, pregnancy was not real barrier or a protective factor against exposure to domestic violence. The literature is not consistent about showing a strategy to reduce exposure of women during pregnancy to different types of violence. Results of many studies those were conducted in 19 countries all over the world (African, Latin American, Asian and European) showed the occurrence of high levels of domestic violence where the accused persons were partners, but this was not necessarily the situation during pregnancy, of course many factors like cultural and social factors were so important determinants of violence caused by partners during pregnancy as Devries and his colleagues documented (2010).

Many Previous studies have also showed that in many circumstances the violence from a partner could start during the first stages of pregnancy mostly if it was unwanted pregnancy from the partner side as reported by Finnbogadóttir et al. (2011).

This study highlighted the strong relationship between level of education and vulnerability to domestic violence faced by pregnant women, it seems that low level of education made these women weaker and less oriented about their rights and how to protect themselves in case of get exposed to different types of violence specially from her intimate partner. There are many different findings in the literature regarding this important point. Saltzman et al, (2003) concluded that who women get less than 12 years of education (basic education) were 4.7 times more vulnerable to get exposed to violence during pregnancy than others who went further with education to be more than 12 years.

In a Canadian study, Stewart and Cecutti (1993) found that women who didn't complete high school were at an increased risk for exposure to violence during pregnancy in comparison to those who completed their high school or higher degree.

In addition to low educational level reported in women subjected to violence during pregnancy, there were other factors such the common use of alcohol, lack of employment and low income levels of the pregnant women and their husbands or intimate partners (Chu et al., 2010). These results are similar to results of this study that showed that most of victims has low level of 
education and their assailants (mostly husbands) had financial problem in $24 \%$ of cases, plus that $17.5 \%$ had other problems like drug or alcohol abuse (a point to be considered with much attention because most of the study participants found it offensive to accuse their husbands for being drug or alcohol abusers).

While the Physical violence was the second type reported with a total of $77.4 \%$, verbal and psychological violence take the 1st place with almost $100 \%$ of cases reported exposure to repeated different verbal and psychological harm from their family members mostly the husband. This comes in accordance to El-Gendy et al., (2016) who found that the husbands are the most common offenders of family violence This study results were like the results founded by Doubova et al. (2007). Also, Deveci et al. (2007), in their respectable research, who found that there was a higher prevalence of verbal/psychological violence in their sample, but this result is unlike to what found by Chu et el. (2010) in United states who found that the physical violence is more common than the verbal and psychological violence.

Logically the person who influence these different types of violence at this special period in woman life, was her intimate partner who lives with her and has the greater chance for attacking her verbally, psychologically and even physically. Same results showed by other researchers like Audi et al. (2012) who concluded that, regarding the perpetrator of domestic violence, the partner was the main assailant in most of the cases, followed by another family member.These results clearly showed that domestic violence specially that against pregnant women represented a major problem in most societies.

\section{RECOMMENDATIONS}

Violence against women is a worldwide critical problem that has deleterious effects on the women, families and societies. Sometimes this violence goes unspoken due to underreporting and fear of the victims from the consequences of reporting violence and lack of domestic violence shelters where the victims can survive for a period of time either alone or with their children. On the other hand, governments should work on increasing the level of women education, offer them more work opportunities in different fields as education helps women to know their constitutional rights and work encourages them to report any violence without fear from financial consequences. Also, more researches on different types of violence against women are necessary in different periods of women life as well as different social levels .Confronting violence against women and empowering them is one of the most important goals of sustainable development 2030 that all countries make a lot of effort to reach them in order to improve the quality of life in their societies.

\section{REFERENCES}

Audi, C.A.; Segall-Corrêa, A.M.; Santiago, S.M.; Pérez-Escamilla, R. (2012): Adverse health events associated with domestic violence during pregnancy among Brazilian women. Midwifery, 28(4):356-61.

Bowen, E.; Heron, J.; Waylen, A.; Wolke, D. (2015): ALSPAC Study Team. Domestic violence risk during and after pregnancy: findings from a British longitudinal study. BJOG, 112(8):10839.

Bunch, C. (1990): Women's rights as human rights: Toward a re-vision of 
human rightsau-thor(s): Charlotte bunch. Hum Rights Q, 12:486-98.

Chu, S.Y.; Goodwin, M.M.; D’Angelo, D.V. (2010): Physical violence against U.S. women around the time of pregnancy, 2004-2007. Am J Prev Med.; 38(3):317-22.

Coker, A.L.; Sanderson, M.; Dong, B. (2004): Partner violence during pregnancy and risk of adverse pregnancy outcomes. Paediatr Perinat Epidemiol,18(4):260-9.

Deveci, S.E.; Acik, Y.; Gulbayrak, C.; Tokdemir, M.; Ayar, A. (2007): Prevalence of domestic violence during pregnancy in Turkish community. Southeast Asian Journal of Tropical Medicine and Public Health. 38(4), 75460 .

Devries, K.M.; Kishor, S.; Johnson, H.; Stockl, H.; Bacchus, L.J.; GarciaMoreno, C. et al. (2010): Intimate partner violence during pregnancy: analysis of prevalence data from 19 countries. Reprod Health Matters, 18(36):158-70.

Doubova, S.V.; Pámanes-González, V.; Billings, D.L.; Torres-Arreola, L.P. (2007). Violencia de pareja en mujeres embarazadas en la ciudad de México. Revista Saúde Pública 41(4), 582-90.

Durand, J.G.; Schraiber, L.B. (2007): Violência na gestação entre usuárias de serviços públi-cos de saúde da Grande São Paulo: prevalência e fatores associados. Rev Bras Epidemiol.; 10(3):310-22.

EL-Gendy, I.; EL- Kholy, S.; Metwally, E.; Mohamed, O. (2016): Medicolegal pattern of family violence problem in Cairo and Giza governorates, Egypt: a four-year retrospective comparative study. The Egyptian Journal of Forensic Sciences and Applied Toxicology, 16(1), pp. 115 -129. doi:10.21608/ejfsat.2016.39956

Finnbogadóttir, H.; Dejin-Karlsson, E.; Dykes, A.K. (2011): A multi-centre cohort study shows no association between experienced violence and labour dystocia in nulliparous women at term. BMC Pregnancy Childbirth, $11: 14$.

Gazmararian, J.A.; Lazorick, S.; Spitz, A.M.; Ballard, T.J.; Saltzman, L.E.; Marks, J.S. (1996): Prevalence of violence against pregnant women. JAMA, 275:1915-20.

Mezey, G.; Bacchus, L.; Bewley, S.; White, S. (2005): Domestic violence, lifetime trauma and psychological health of child bearing women. BJOG, 112(2):197-204.

Nasir, K.; Hyder, A.A. (2003): Violence against pregnant women in developing countries: re-view of evidence. Eur $\mathbf{J}$ Public Health, 13(2):105-7.

Saltzman, L.E., Johnson, C.H., Gilbert, B.C. et al. (2003): Matern Child Health J, 7: 31 https://doi.org/10.1023/A:10225895010 39

Stewart, D.E.; Cecutti, A. (1993): Physical abuse in pregnancy. CMAJ, 1;149(9):1257-63. 


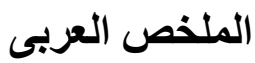

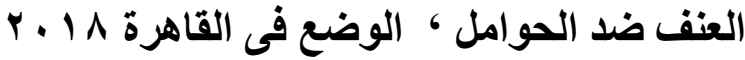

امانى عبد الفتاح ، ميرفت حمدى ، غادة حسبو

قسم الطب الثر عى و السموم الأكلينيكية ، كلية الطب ، جامعة القاهرة

الملخص: اي فعل من أفعال العنف القائم على نوع الجنس ينتج عنه أو يحتمل أن ينسبب في ضرر أو معاناة جسدية أو جنسية أو عقلية للنساء ، بما في ذلك التهديد بمثل هذه الأفعال أو الإكراه أو الحرمان التعسفي من الحرية ، سواء كان ذلك الكي في الحياة

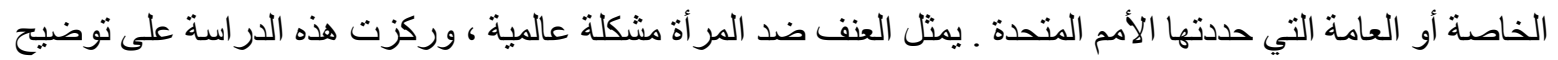

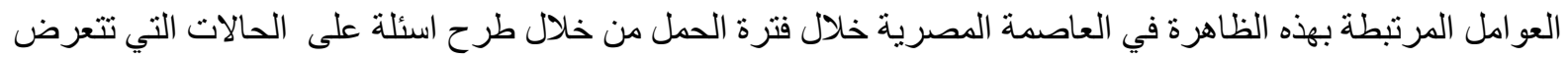
للعنف خلال هذه الفترة ، ولتسمية العو اقب و المضاعفات الثنائعة بسبب التعرض لأنو اع مختلفة من العنف. وقد قامت تلك لكان

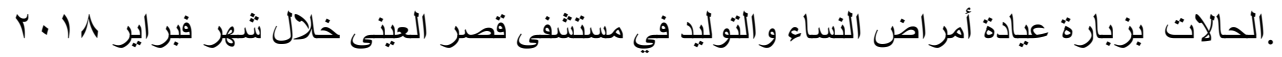

هناك مضاعفات خطيرة للعنف أثناء الحمل ، ولكن يبدو أن التأثير النفسى يمثل المشكلة الرئيسية بعد التعرض للعنف في هذه

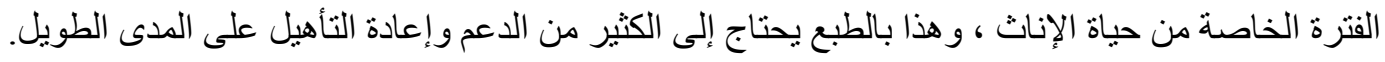
كلمات مفتاحية : العنف القائم على النوع الاجتماعي ، العنف أثناء الحمل ، معاناة النساء ، المضاعفات 